\title{
CULTURA COOPERATIVA Y GESTIÓN EMPRESARIAL EN LA CUENCA LECHERA CORDOBESA-SANTAFESINA. ARGENTINA, FINES DEL SIGLO XIX A 1970
}

\author{
COOPERATIVE CULTURE AND BUSINESS \\ MANAGEMENT IN THE DAIRY REGION OF CORDOBA \\ AND SANTA FE. ARGENTINA, FROM THE END OF THE \\ 19TH CENTURY TO 1970
}

\author{
Gabriela Olivera \\ Universidad Nacional de Córdoba, Córdoba, Argentina, <golivera@ffyh.unc.edu.ar>
}

Resumen: Este artículo presenta resultados de una investigación basada en fuentes primarias. Revaloriza el conocimiento de procesos históricos espacial y temporalmente particularizados. Apunta a explicar las transformaciones que tenían lugar en la cuenca lechera cordobesa-santafesina en Argentina cuando se intensificaba la actividad agroindustrial bajo el liderazgo de la empresa cooperativa Sancor (Fábrica de Manteca Sancor Cooperativas Limitadas). Esta empresa promovía un modelo de incorporación de tecnologías de avanzada y en el despliegue de sus capacidades organizativas subyacían ciertos valores culturales vinculados al cooperativismo.

Palabras clave: cooperativas, agroindustria láctea, cuenca lechera.

Abstract: This article presents the results and findings of an investigation based on primary sources. It reappraises the knowledge of temporally and spatially-situated historical processes. It seeks to explain the transformations that took place in the Argentine dairy region of Córdoba-Santa Fe at times when there was an intensification of agro-industrial activity under the leadership of the co-operative company Sancor (Sancor Butter Factory Co-operative Limited). This company promoted a model that consisted in incorporating advanced technologies. In the deployment of its organizational capabilities, there were certain underlying cooperativism related cultural values.

Key words: cooperatives, dairy agribusiness, dairy region.

Fecha de recepción: marzo de 2012. Fecha de aceptación: mayo de 2012.

Am. Lat. Hist. Econ., año 20, núm. 1, enero-abril, 2013, pp. 199-232 


\section{INTRODUCCIÓN}

$\mathrm{E}$ 1 propósito de este artículo es el estudio histórico de las transformaciones que experimentó la agroindustria láctea en una cuenca lechera argentina desde fines del siglo XIX hasta la década de 1970. La noción de cuenca implica una "delimitación regional" con base en "áreas productoras lácteas". "La cantidad de tambos ${ }^{2}$ y de animales con que se opera" y el criterio cualitativo de la existencia de "un mismo patrón sociotécnico organizacional" -con la aclaración de que este patrón se podría dar "con diferentes intensidades"-, marcan la preponderancia de la actividad láctea de "un espacio homogéneo dentro de cada cuenca". Molinari trabaja con una conceptualización que enfatiza la importancia del "patrón de localización industrial" y de los "centros urbanos de consumo". ${ }^{3}$ Con base en estos indicadores se delimitan las principales cuencas lecheras de Argentina: oeste, abasto de Buenos Aires, y la cordobesa-santafesina. Esta última representaba $53 \%$ de los tambos y $50 \%$ de las existencias bovinas lecheras nacionales en $1988 .{ }^{4}$

El estudio comienza a fines del siglo XIX, cuando la materia prima era provista por pequeños productores tamberos que realizaban esta actividad como parte de un conjunto de actividades agropecuarias diversificadas y la entregaban a empresarios para su elaboración agroindustrial; procura captar los procesos históricos que subyacían en las transformaciones que tenían lugar en el territorio, la economía y sus actores cuando se conformaba la cuenca lechera, se intensificaba la actividad agroindustrial, lo que ocurría con el surgimiento y el crecimiento de la entidad cooperativa de segundo grado Sancor (Fábrica de Manteca ${ }^{5}$ Sancor Cooperativas Limitadas). ${ }^{6}$ Este estudio concluye en un momento de fuerte expansión agroindustrial, principalmente en el mercado interno, bajo el liderazgo de Sancor durante la década de 1970.

Dos hipótesis han guiado esta investigación. En primer lugar se plantea que Sancor promovió un modelo empresarial de incorporación de tecnologías de avanzada en la elaboración agroindustrial que incentivó un modelo de "empresa tambo". Este modelo no podría haberse desarro-

${ }^{1}$ Posada y Pucciarelli, "Producción", 1977, p. 591.

${ }^{2}$ Tambos son las unidades productivas proveedoras de la materia prima láctea.

${ }^{3}$ Molinari, "Viejos", 2009, p. 66.

${ }^{4}$ Posada y Puciarelli, "Producción", 1977, p. 593.

${ }^{5}$ Se aclara - para evitar confusiones- que en Argentina se usa el vocablo "manteca" para nombrar al producto alimenticio obtenido de la crema de leche por batido. En España y en algunos países de América Latina se usa en cambio la palabra mantequilla para designar a este producto y manteca a la grasa de los animales, especialmente de cerdo.

${ }^{6}$ En la actualidad Sancor ocupa el primer lugar entre los exportadores argentinos de lácteos. Véase Sancor, Exportaciones, <www.sancor.com>. [Consulta: 7 de enero de 2012.] 
llado de no existir su estructura burocrática cada vez más compleja, ${ }^{7}$ la que incorporaba, de manera creciente, pautas de gerencias empresariales. En segundo lugar se afirma que la otra clave explicativa de la trayectoria exitosa de la empresa Sancor radica en su particular perfil institucional. En el despliegue de las capacidades organizativas subyacían ciertos valores culturales vinculados a la doctrina cooperativa. Tal como planteara Lipartito, las capacidades organizativas de las empresas remiten a un sustrato de valores culturales que participan de manera importante como las estructuras formales (multidivisionales) en el desempeño de la firma. Estos valores impregnan la acción innovadora y creativa de la organización empresarial. Recupera la noción de empresa no sólo como actor económico, sino también cultural innovador, antes que como "un recipiente pasivo de las instrucciones que vienen del mercado".

Esta cultura cooperativa tenía un discurso que argumentaba a favor de la vinculación de la entidad de segundo grado (empresa Sancor) con las cooperativas primarias. Se afirmaba: esta vinculación -que operaba en términos económicos como integración vertical en un momento histórico en que esta agroindustria no estaba integrada verticalmente- permitía incrementar el ingreso de los productores, evitando la intermediación comercial, y que sustituía al industrial privado. Los diferentes actores de la agroindustria (directivos, técnicos y productores tamberos) eran considerados como socios solidarios cooperativos, lo que operaba cohesionando a la institución empresarial. ${ }^{9}$ Sancor desplegaba un conjunto de incentivos económicos y simbólicos a la modernización de los tambos de los productores de la materia prima, incorporaba tecnologías de avanzada en sus plantas industriales, se ocupaba de gestionar el acceso a los mercados de colocación (interno y externo) y al crédito oficial, el cual fue una fuente relevante de financiamiento de esta empresa. ${ }^{10}$

En el primer apartado de este artículo se presenta una sucinta contextualización histórica de la industria láctea y del cooperativismo en Argen-

${ }^{7}$ El término burocrático no está utilizado en el sentido común, sino en el weberiano. Véase Weber, Economía, 1984.

${ }^{8}$ Lipartito, "Culture", 1995, pp. 5-10.

${ }^{9}$ La noción de cohesión institucional en modo alguno excluye la existencia de tensiones o, incluso, en determinadas coyunturas conflictos abiertos, entre actores con objetivos, intereses e injerencia diferencial en la toma de decisiones. Estas tensiones pueden ser explicadas de manera sistemática en el modelo de organización institucional paradojal, en el que existe "una estructura representacional que trata de 'resolver' a través de un proceso burocrático, la situación -contradictoria y paradójica- de sostener en la organización cooperativa, en términos de Max Weber, acciones racionales con arreglos a fines (la constitución de una empresa cooperativa donde cuenta el rendimiento económico) y, simultáneamente, acciones racionales con arreglo a valores (doctrina cooperativa)". Lattuada y Renold, Cooperativismo, 2004, p. 91. Véase también Weber, Economía, 1984, p. 20.

${ }^{10}$ Olivera, "Agroindustria”, 2011. 
tina. En el segundo se realiza una presentación sobre la cuenca cordobesasantafesina desde sus orígenes hasta la década de 1930, considerando a sus principales protagonistas: el tambo en el contexto de la pequeña explotación agropecuaria diversificada, las empresas privadas, las cooperativas y otras asociaciones dedicadas a la actividad lechera. En el tercer apartado se consideran las transformaciones que experimentó la cuenca con la gestación de un nuevo modelo lácteo empresarial basado en las innovaciones tecnológicas y el incremento de la productividad bajo el liderazgo de Sancor. Finalmente, consideramos aspectos culturales e institucionales relativos a este modelo.

\section{ORIGEN Y EXPANSIÓN DE LA INDUSTRIA LÁCTEA EN ARGENTINA}

En el último cuarto del siglo XIX Argentina se incorporó a la división internacional del trabajo como proveedora de materias primas de clima templado, principalmente ganado y cereales. Inglaterra era su principal mercado de colocación y también en la provisión de manufacturas industriales. El principal eje de la economía argentina pasaba por el mercado externo. ${ }^{11}$ No obstante, durante esta etapa hubo cierto desarrollo industrial vinculado al mercado interno y derivado del "bien primario exportable", ya que para adecuar los niveles de producción agraria a la demanda agregada se generaba, por un lado, demanda de insumos tecnológicos que si bien eran cubiertos mediante la importación, inducían al surgimiento de talleres de reparación y fabricación de partes de la maquinaria agrícola $y$, por otro, actuaban como "eslabones hacia delante", promoviendo el desarrollo de las industrias derivadas de la producción agropecuaria. ${ }^{12}$ Así, cobraron impulso las industrias harinera, frigorífica, azucarera, vitivinícola y láctea.

El desarrollo histórico de la industria láctea, a diferencia de las otras mencionadas, está escasamente estudiado. Presenta, además, la particularidad de que, desde sus orígenes, estuvo vinculada tanto al mercado interno como al externo, y en la cual la presencia del cooperativismo fue relevante. Al expandirse experimentó procesos de modernización que implicaban la incorporación de un conjunto de tecnologías de avanzada referidas tanto a la producción de leche fluida como a la de productos derivados, principalmente manteca y caseína. El tendido de la red ferroviaria basada originalmente en el capital inglés permitió transportar la producción láctea desde el interior argentino, sobre todo desde la región pampeana,

${ }^{11}$ Gerchunoff y Llach, Ciclo, 2000, pp. 18-34.

${ }^{12}$ Geller, "Crecimiento", 1975, pp. 156-200. 
epicentro de la agricultura de exportación, a los principales centros urbanos y a los puertos, dinamizando así los mercados interno y externo. Su conformación era incentivada por el "aluvión" inmigratorio europeo que experimentó Argentina desde principios del siglo XIX y durante las primeras décadas del siglo $\mathrm{Xx} .^{13}$

Inglaterra fue el principal mercado para la manteca y el estadunidense para la caseína ${ }^{14}$ argentina. La relevancia de este mercado no se refería sólo a la colocación de la manteca, sino también a la inversión inglesa en este sector. Capitales locales se asociaron a los capitales inglés y escandinavo. $\mathrm{Al}$ respecto, mencionamos por su importancia pionera a la empresa La Escandinavia Argentina y los consignatarios ingleses de la producción exportada, la firma Ellis, Kislingbury y Co., de Londres. La Escandinavia pudo levantar en 1897 su fábrica y varias cremerías. ${ }^{15}$ Otro caso relevante de asociación de capital inglés con local fue el de The River Plate Dairy Co. Ltd., empresa que trabajaba en la cuenca lechera bajo estudio, y La Victoria. La primera inició sus actividades en 1901. La Victoria se ubicaba en Rosario y se abastecía de la producción santafesina. ${ }^{16}$ El proceso expansivo de la industria láctea requirió de la importación de equipo industrial destinado a la producción de leche, los derivados lácteos y se conformó un sector específicamente introductor. A finales de la primera guerra mundial -y según el Manual de la Bolsa de Comercio- existían ya empresas lácteas importantes. Las cuatro más relevantes eran La Vascongada, S. A., La Martona, The River Plate Dairy Co. Ltd. y la Compañía Nacional de Caseína. ${ }^{17}$ Desafortunadamente no existen estudios de caso sobre empresas lácteas hasta la conformación de los complejos agroindustriales durante la década de 1990 .

Hubo dos vertientes sociales en el origen y la expansión de la lechería argentina. Por un lado, se destaca la participación pionera de los co-

${ }^{13}$ Gerchunoff y Llach, Ciclo, 2000, pp. 34-55.

${ }^{14}$ La caseína se comenzó a elaborar en Argentina en 1937, a partir de las experimentaciones llevadas a cabo por el sueco Andrés Gustavo Elowson. La caseína se elaboraba haciendo precipitar -mediante ácidos sulfúricos, clorhídricos y acéticos- a la "leche descremada", hasta entonces deshecho de la industria cremera. Se echaba en pozos y zanjas cavadas, porque esta solución se descomponía y actuaba como agente de infección ambiental. Por esto, el descubrimiento de Elowson fue bien recibido por los industriales lecheros. Cuando se produjo esta invención existían sólo tres elaboradores: Estados Unidos, Italia y Francia, los que mantenían celosamente sus respectivas patentes de invención. Ferrero y Cravero, Origen, 1988, p. 14.

${ }^{15}$ Estación de desnate o cremería. "Recibida la leche entera, se procede al descremado y el suero blanco obtenido se destina a la alimentación humana o animal, a la fabricación de caseína, quesos magros, etc. La crema puede utilizarse directamente como alimento, o bien, en la elaboración de manteca", en Ferrari, Industria, 1978, p. 19.

${ }^{16}$ Ferrero y Cravero, Origen, 1988, p. 23.

${ }^{17}$ Dorfman, Historia, 1970, p. 306. 
$\operatorname{lonos}^{18}$ (principalmente vascos, suizos, escandinavos e italianos), quienes comenzaron a desarrollar la actividad tambera, organizaron las primeras cremerías, fueron inventores e introductores de maquinaria en la industria láctea. Algunos de estos, a través de la acumulación alcanzada en la actividad lechera, accedieron a la propiedad de la tierra y, en algunos casos, se convirtieron en estancieros. Por otro lado, un sector de grandes estancieros, con una dotación tal de capital que podía hacer "cabaña"19 con las razas bovinas lecheras, se habría sumado cuando advertía la expansión y el promisorio futuro de esta actividad, el cual se expresaba en una creciente valorización de las razas lecheras y del precio de la tierra apta para ganado lechero. ${ }^{20}$

\section{El COOPERATIVISMO LÁCTEO Y EL SURGIMIENTO DE SANCOR}

Los orígenes del cooperativismo agrario se remontan a fines del siglo XIX. Muchas cooperativas fueron fundadas por colonos inmigrantes europeos que buscaban replicar experiencias colectivas de sus países de origen, las que contribuyeron a retroalimentar su identificación y pertenencia regional.

En la década de 1930 las cooperativas agrarias eran ya relevantes en el movimiento cooperativo nacional. Si se considera el porcentaje de capital aportado por los grupos de cooperativas agrarias en el conjunto de las sociedades cooperativas, se observa que las agroganaderas y tamberas ocupaban el primer lugar. Estas sumaban conjuntamente $72.12 \%$ del total en $1937 .^{21}$

Existieron tres grandes vertientes cooperativas. Una ligada al gremialismo rural y a la Federación Agraria Argentina, otra asociada a la Asociación de Cooperativas Argentinas y una tercera, especializada en la lechería. En las dos primeras vertientes prevalecía la orientación agrícolaganadera. Se dedicaban principalmente a la comercialización agrícola y

\footnotetext{
${ }^{18}$ En Argentina durante la segunda mitad del siglo XIX una gran cantidad de tierras públicas se encontraba en poder de los gobiernos provinciales. Los procesos iniciales de colonización fueron organizados por estos estados y apuntalados por una fuerte demanda internacional de cereales; tempranamente, las iniciativas de colonización privada cobraron mucho más significación que las públicas. Los gobiernos provinciales cedieron tierras a empresarios y compañías privadas; a cambio recibían recursos monetarios. En la colonización (estatal y privada) se entregaba al agricultor del asentamiento -denominado como "colono" y que en general era inmigrante europeo-, además de la tierra, créditos en forma de alimentos, semillas y otros insumos productivos. Barsky y Gelman, Historia, 2001, pp. 164-170.

${ }^{19}$ Establecimientos para el engorde del ganado, en general basado en razas refinadas.

${ }^{20}$ Ferrero y Cravero, Origen, 1988, pp. 28-39.

${ }^{21}$ Yuri, Quince, 1972, p. 68.
} 
eran también cooperativas de consumo. La tercera vertiente se orientaba a la producción, la comercialización, la agroindustrialización láctea y estaba organizada en diferentes entidades de primero y segundo grados. ${ }^{22}$

La única vertiente con gravitación macroeconómica desde la década de 1930 fue el cooperativismo lácteo. Según información producida por Sancor, en 1942 la producción de manteca del conjunto de las entidades cooperativas representaba $50 \%$ del total nacional y en la caseína alcanzaba $40 \%{ }^{23}$ Una vía precursora del trabajo cooperativo en la lechería estuvo representada por las primeras cooperativas agropecuarias (y no específicamente tamberas). No obstante $-\mathrm{y}$ como se puede observar en los siguientes apartados de este texto-, las cooperativas específicamente lácteas se concentraban en el territorio de la cuenca cordobesa-santafesina.

En la creación de Sancor, 1938, tuvo lugar un debate entre los diferentes grupos y dirigentes locales. ¿Cuál era la forma societaria más conveniente para el mejoramiento de las condiciones de producción agroindustrial y de comercialización de los productores tamberos? Para propender a beneficiar a los productores, chabía que formar una asociación gremial, una cooperativa o una empresa? No existía un sustrato cultural ni institucional que identificara clara y taxativamente a las diferentes organizaciones. Finalmente, prevaleció el grupo dirigente denominado movimiento de Brinkmann -en el cual se encuadraban delegados de las zonas de Sunchales, Moisés Ville y Brinkmann- frente al de San Jerónimo, que quería formar una asociación de carácter gremial. ${ }^{24}$

El grupo de Brinkmann planteaba que, para defender los frutos del trabajo de los productores tamberos, había que crear una fábrica cooperativa que se dedicara a la elaboración agroindustrial y a la comercialización de la crema producida por las cooperativas primarias de la zona. Con este objetivo se formó, en 1937, la "comisión provisoria proinstalación de fábrica de manteca propia". Esta comisión señalaba que la presencia de una cooperativa de segundo grado "libre y democrática", "con profundo contenido humano y social", que apuntara a una "distribución equitativa de la riqueza" se garantizaría a través de la construcción de una "empresa láctea". Las cooperativas sólo lograrían independizarse del industrial privado y obtener mejores precios por la grasa butirométrica contenida en la crema, instalando una planta industrial "propia" (es decir cooperativa). Esta cooperativa industrial debería ser "fuerte", poder acceder a tecnológicas y "gravitar en el mercado". ${ }^{25}$ Es destacable cómo la idea fundante

\footnotetext{
${ }^{22}$ Olivera, "Cooperativismo", 2012, pp. 230-240.

${ }^{23}$ Revista Sancor, núm. 1, junio-julio de 1942, pp. 19-20.

${ }^{24}$ Memorias, ejercicio 1945, pp. 12-14.

${ }^{25}$ Los primeros, s. a., pp. 2-3 y 28.
} 
de Sancor no fue la defensa gremial de los intereses de los productores frente a los industriales, sino en cambio, la noción de construcción de una empresa industrial que integrara la fase de producción primaria, con un perfil institucional cooperativo. Así, puede caracterizarse a esta corriente cooperativa como de tipo empresarial, ya que incluía este tipo de gerenciamiento y difundiría valores culturales ligados a crear condiciones para competir en el mercado lácteo e incorporar tecnologías en sus plantas industriales y también en el tambo.

\section{ORIGEN Y CONFORMACIÓN DE LA CUENCA LECHERA CORDOBESA-SANTAFESINA (FINES DEL SIGLO XIX A DÉCADA DE 1930)}

Los orígenes de la cuenca se remontan a la colonización estatal y privada sobre tierras fiscales durante el último tercio del siglo XIX. El Estado entregaba vacas lecheras -junto a los implementos agrícolas básicos- a los colonos. Italianos, franceses, españoles, suizos, alemanes, belgas, ingleses y judíos fueron los pioneros en el desarrollo de la lechería. Se trataba de producciones domésticas desarrolladas en pequeña escala. El excedente de la leche y la manteca que se producían se vendía. Esta actividad se llevaba adelante en un contexto de economía agraria diversificada: en la "chacra" mixta. ${ }^{26}$ El desarrollo del cooperativismo fue temprano e importante ya que estos inmigrantes traían tradiciones lecheras y cooperativistas de sus países de origen. La producción tambera alcanzó mayor expresión en las zonas beneficiadas por las colonizaciones. No obstante, el crecimiento se vio trabado por la falta de redes camineras, de medios de conservación y de transporte de los lacticinios.

La mayoría de los tambos tenía pisos de tierra; carecían de instalaciones y piletas de refrescado, necesarias para reducir la cantidad de microbios; empleaba vacunos que no eran específicamente lecheros; ignoraba la existencia del ordeñe mecánico y del escalonamiento en las pariciones para evitar interrupciones en la producción. ${ }^{27}$ Con la leche que se acopiaba de estos tambos -de un radio de influencia generalmente no superior a una legua- se producía la crema, materia necesaria para la elaboración ulterior de la manteca en las fábricas. Las cremerías eran -desde el punto de vista técnico-económico- unidades industriales elementales en las cuales se realizaba el desnatado mecánico de la leche. La fabricación de la crema resolvía, en parte, el tema de la conservación del producto lácteo, dados

${ }^{26}$ Orígenes, 1988, p. 35.

${ }^{27}$ Rodríguez, Juan, 1970, pp. 50-70. 


\section{MAPA 1. UBICACIÓN DE LA CUENCA LECHERA CORDOBESA- SANTAFESINA EN ARGENTINA}

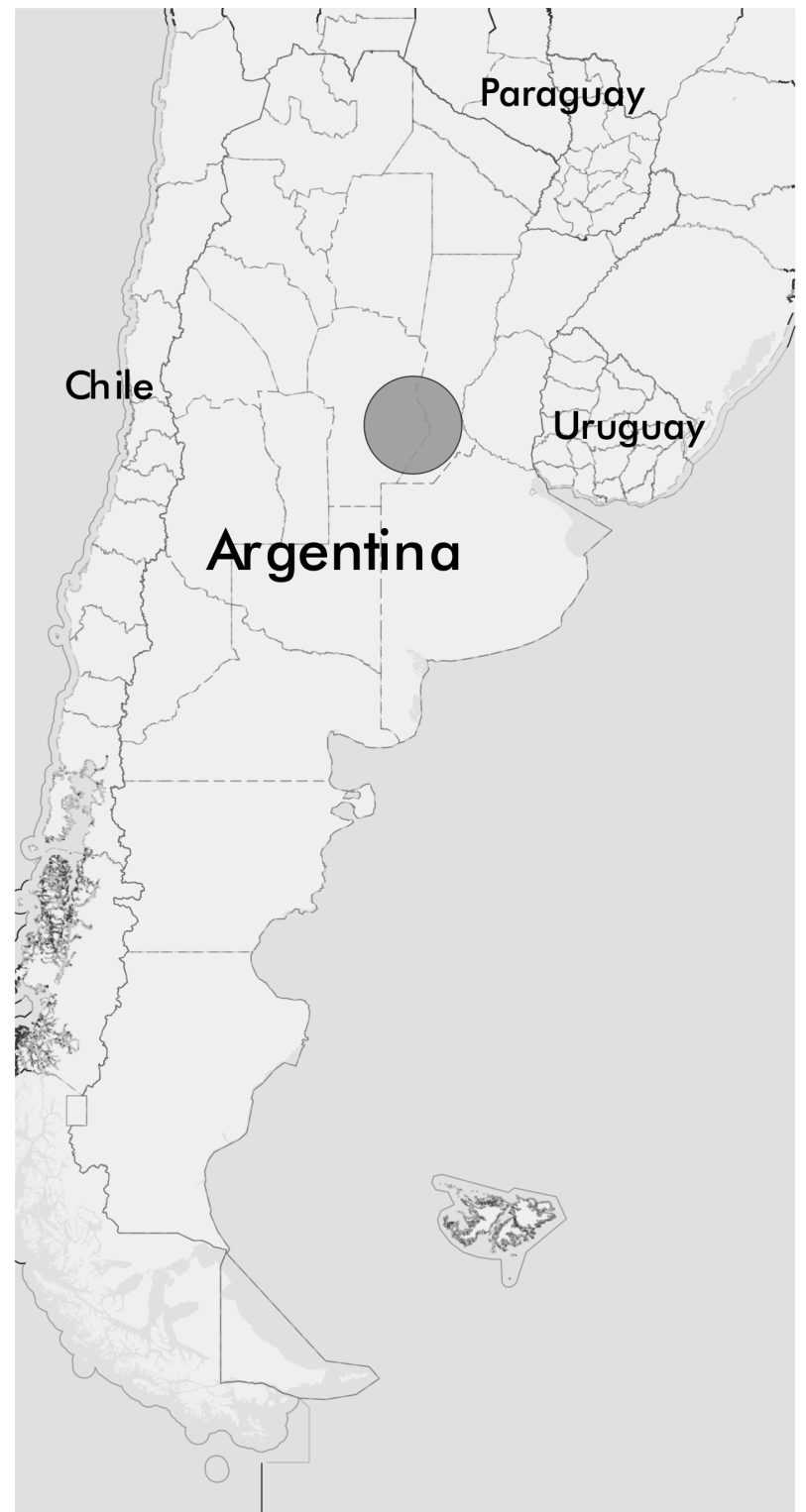

Fuente: elaboración propia con base en (C) OpenStreetMap contributors, CC BY-SA, <http:// www.openstreetmap.org/ $>\mathrm{y}<\mathrm{www} . c r e a t i v e c o m m o n s . o r g>$. [Consulta 29 de julio de 2012.] 
los problemas existentes en el transporte, ya que su tenor graso se conserva más tiempo que la leche fluida. ${ }^{28}$

La empresa más importante que compraba crema y leche a los tamberos fue The River Plate Dairy Co. Ltd. Esta empresa llegó de la mano del constructor de la primera cremería, el irlandés Santiago Shine. Instaló la primera cremería en San Jerónimo en 1899. Hasta la década de 1930 se expandiría hacia el oeste santafesino y llegaría a trabajar con 30 cremerías (privadas y cooperativas). Estas irían contribuyendo a la conformación de la cuenca y se ubicaban en los núcleos urbanos de Rafaela, Sunchales, Morteros, Brinkmann, Moisés Ville y Palacios (véase mapa 2).

Actuaban también en la zona las firmas Swift -instalada en Rosario- y Salvador Macagno y Cía., con plantas industriales en Santa Fe y Rafaela. En la colonia de Sunchales funcionaba una fábrica de quesos de la compañía Aristo, de "mediana capacidad y buena tecnología". En la localidad de Brinkmann operaba una fábrica de manteca y algunas queserías diseminadas por las colonias, todas ellas "con empleo de tecnologías muy rudimentarias". El crecimiento de las cooperativas primarias con actividad en lechería era importante ya en la década de 1930. Llegaba entonces a 55 asociaciones. $^{29}$

Además de estas cooperativas primarias se destacaban por su importancia la Asociación Unión Tamberos de Franck, la Unión Cooperativa Limitada San Carlos, la Sociedad Cooperativa de Tamberos de la zona de Rosario y Sancor. La primera entidad mencionada revestía carácter de sociedad civil y realizaba también actividades de tipo gremial. Instaló su primera cremería en las Tunas, Santa Fe, con dinero y trabajo aportado por los socios. En 1934 abrió su propia fábrica de manteca en la ciudad de Santa Fe. ${ }^{30}$

La Unión Cooperativa Limitada San Carlos fue la primera cooperativa tambera de segundo grado de Sudamérica. Surgió en 1930 en la colonia de San Carlos Centro, Santa Fe, donde instaló su propia fábrica de manteca. Se constituyó de la unión de cuatro cooperativas tamberas primarias ubicadas en Matilde, San Agustín, Gesler y San Carlos norte, Santa Fe. Por último, la Sociedad Cooperativa de Tamberos de la zona de Rosario comenzó sus actividades como entidad gremial de tamberos. Desde 1938 reformó sus estatutos y se transformó en cooperativa. ${ }^{31}$

${ }^{28}$ Ferrero y Cravero, Origen, 1988, p. 17.

${ }^{29}$ Los primeros, s. a., pp. 26 y 235.

${ }^{30}$ Orígenes, 1988 , p. 53.

${ }^{31}$ En 1963 instaló una usina pasteurizadora, con equipos para la elaboración de leche en polvo y fábricas de queso, en ibid. 


\section{MAPA 2. LA CUENCA CORDOBESA-SANTAFESINA \\ EN LA DÉCADA DE 1930}

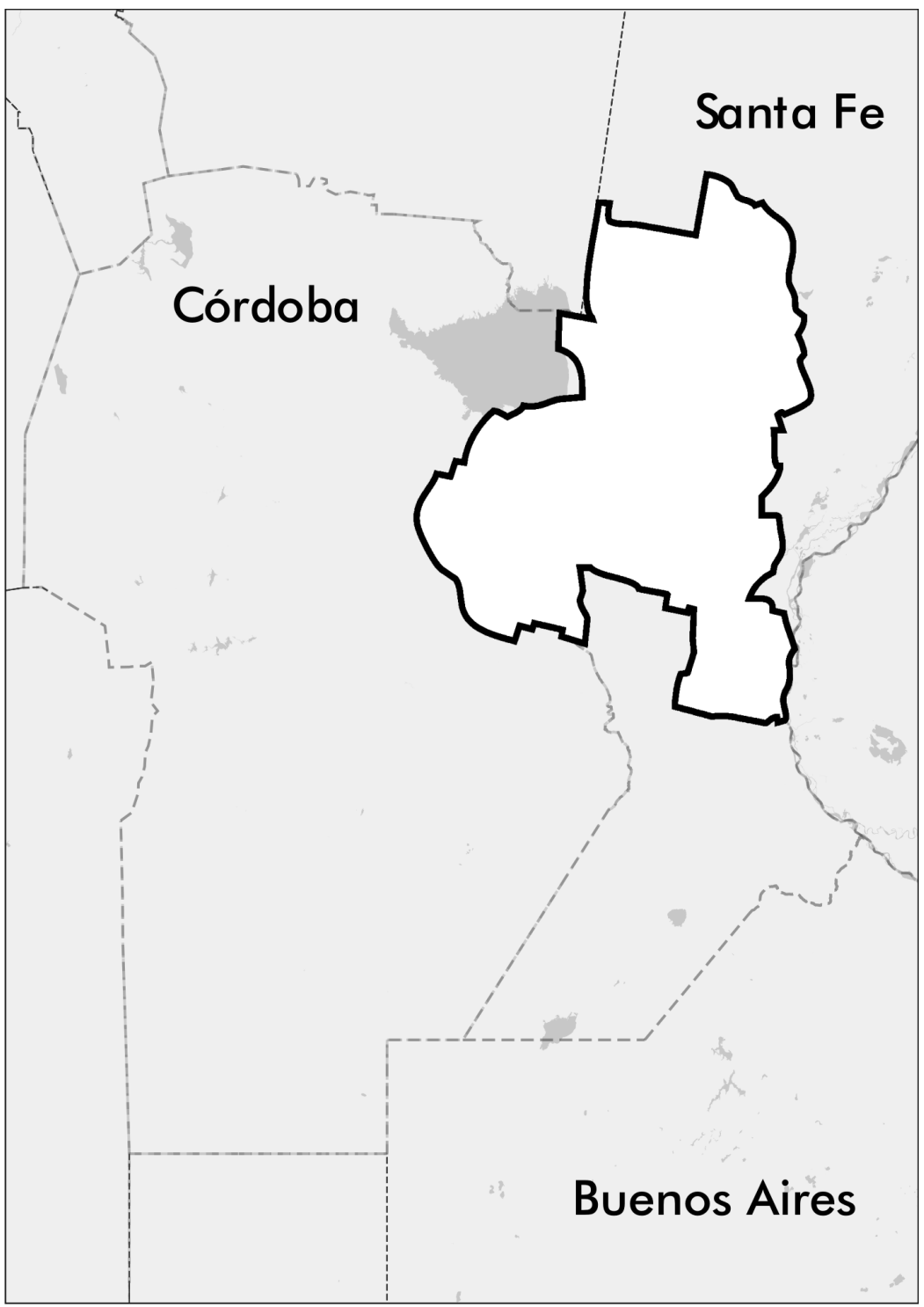

Fuentes: elaboración propia con base en (C) OpenStreetMap contributors, CC BY-SA, $<$ http://www.openstreetmap.org/> y <www.creativecommons.org > . [Consulta 29 de julio de 2012.] Los primeros, s. a., p. 26, y Orígenes, 1988, pp. 2-103. 


\section{LA CUENCA LECHERA CORDOBESA-SANTAFESINA \\ BAJO EL LIDERAZGO DE SANCOR \\ (DÉCADA DE 1930 A 1970)}

Desde la década de 1930 se observan trayectorias exitosas en las asociaciones y entidades cooperativas. No obstante, Sancor fue la empresa cooperativa que tuvo un desempeño más dinámico. Durante la década de 1940 consolidó su presencia en la cuenca lechera preexistente. Desde 1938 hasta 1947 la cantidad de cooperativas asociadas se había incrementado de 16 a 155 . Durante 1950 expandió su radio de acción a la antigua cuenca lechera de Villa María, Córdoba. En 1952 contaba con 234 cooperativas adheridas. En la década de 1960 la geografía de Sancor alcanzaba al sur cordobés y santafesino, tradicionalmente agrícola (véase mapa 3). Según la memoria y balance de la organización en 1970, Sancor tenía 416 cooperativas asociadas. ${ }^{32}$

La contracara del proceso expansivo fue el progresivo retiro de las otras empresas que venían trabajando en la zona. Algunas fábricas -como el caso de la firma Spirandelli de Brinkmann- tuvieron que vender sus plantas industriales a los productores cooperativos. Técnicos que habían trabajado para la firma The River Dairy Co. Ltd. pasaron a prestar servicio en Sancor y el conjunto de las sociedades civiles cremeras que existían en la zona se transformó en cooperativas. ${ }^{33}$

\section{El nuevo modelo lácteo: innovaciones tecnológicas y alta productividad empresarial}

Cuando se analizan las modificaciones productivas y comerciales que experimentó la cuenca láctea cordobesa-santafesina es necesario considerar que las nuevas prácticas productivas connotaban un conjunto de innovaciones en el empleo de las técnicas de la alimentación, el manejo y la reproducción de los animales, el transporte en la producción láctea, nuevas pautas de sanidad en el tambo, en el tratamiento industrial de la leche y los productos derivados. Estas innovaciones apuntaban a incrementar el volumen de la producción láctea y a aumentar la productividad empresarial en el tambo y en la industria láctea. Para el logro de una "producción sana y abundante" los aspectos sanitarios adquirirían una significación que no habían tenido anteriormente. Estas técnicas implicaban la aplicación de

\footnotetext{
${ }^{32}$ Memorias, ejercicio 1971-1972, pp. 7-12.

${ }^{33}$ Revista Sancor, núm. 295, abril-mayo de 1969, p. 19; núm. 367, abril-mayo de 1976, pp. 33 34, y núm. 394, abril-mayo de 1979, pp. 4-5.
} 


\section{MAPA 3. LA CUENCA CORDOBESA-SANTAFESINA \\ A PRINCIPIOS DE 1970}

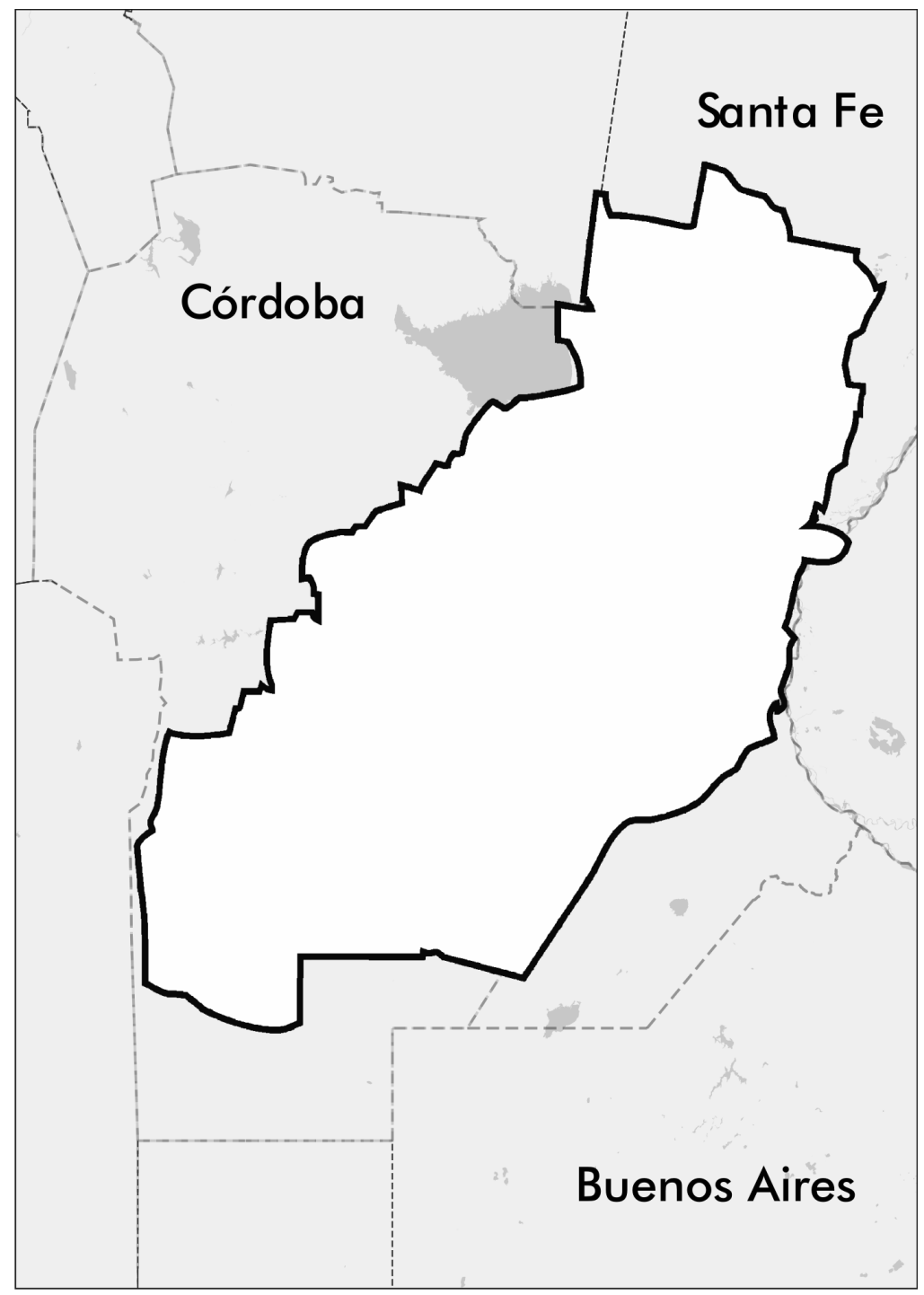

Fuente: elaboración propia con base en (C) OpenStreetMap contributors, CC BY-SA, <http:// www.openstreetmap.org/> y <www.creativecommons.org>. [Consulta 29 de julio de 2012.] Los primeros, s. a., p. 26; Orígenes, 1988, pp. 2-103; Memorias, ejercicio 1970, pp. 7-12, y Reporte, 2010, pp. 11-13. 
conocimientos provenientes, entre otras ciencias, de la ingeniería, en las instalaciones y en los aspectos agronómicos; la zootecnia, en las mejoras genéticas a través de la implantación de ganado lechero, y la bioquímica.

\section{TRANSFORMACIONES ECONÓMICAS Y TECNOLÓGICAS EN EL TAMBO}

"Todo el conjunto del negocio del tambo debe ser atendido y manejado con habilidad de empresario," ${ }^{34}$ aconsejaba el Instituto Nacional de Tecnología Agropecuaria y afirmaba que esto se lograría mejorando los rendimientos de la producción de leche, ya sea por un aumento del volumen del negocio o por un aumento de la productividad. La segunda cuestión se cuantificaba, de manera relevante, a través de un incremento de los porcentuales de grasa butirométrica por litro de leche. El incorporar más capital en la empresatambo se justificaba cuando aumentaban los rendimientos y disminuían los costos. Para lograr estos objetivos era crucial el refinamiento del ganado, es decir, el reemplazo de las razas bovinas existentes por razas lecheras. ${ }^{35}$

El proceso de sucesivos reemplazos de ganado criollo por ganado refinado en el tambo implicaba "buenos orígenes de sangre y producción controlada”. La primera cuestión se vinculaba al registro de los antecedentes de los animales en las cabañas, establecimientos especializados en la producción de reproductores y las vacas de razas lecheras de alta calidad y, la segunda, al control de la reproducción animal en el tambo.

A través de los certámenes realizados anualmente por la Sociedad Rural Argentina se ponía de manifiesto el creciente interés por el refinamiento ganadero para uso lechero. El interés se intensificó desde finales de la década de 1930 y durante la de 1940. Aumentaba el número de animales de razas lecheras inscritos para los remates y el precio al que se vendían. La raza holando-argentina ${ }^{36}$ era la que alcanzaba mayor difusión. ${ }^{37}$

El cuadro 1 muestra las existencias ganaderas en los departamentos de Córdoba y Santa Fe que conformaban la cuenca lechera cordobesa-santafesina en 1937. Las razas lecheras que se habían introducido -holandesa y normanda- eran muy pocas en relación con el rodeo vacuno total. La raza vacuna shorthorn, que tiene la particularidad de ser empleada para doble uso (carne y leche) en mayor medida que la holandesa o normanda, esta-

${ }^{34}$ Maubecin, "Crédito", 1972, pp. 2-5.

${ }^{35}$ Ibid.

${ }^{36}$ La raza holandesa fue introducida desde los Países Bajos a fines del siglo XIX, derivada de la raza holstein. Fue adaptada y desarrollada en Argentina y Uruguay como holando-argentina, destinándose a la producción de leche pero también de carne. Barsky y Gelman, Historia, 2001, p. 159.

${ }^{37}$ Bizzozero, "Problema”, 1947, pp. 339-341. 
ba más difundida que las más específicamente lácteas. La proporción de vacunos de doble uso y específicamente lecheros en relación con el total ganadero, al que denominamos índice de refinamiento lechero, no llegaba ni siquiera a $1 \%(0.45 \%)$. Esto significa que los tambos de la cuenca no habían invertido en refinar sus rodeos vacunos.

Para 1960 la situación de la cuenca ha cambiado sustancialmente. ${ }^{38} \mathrm{La}$ cuenca se ha ampliado territorialmente hacia el sur santafesino y el sureste cordobés. Las existencias ganaderas se han incrementado desde 1869971 cabezas en 1937 a 7435735 vacunos en 1960, es decir, casi cuatro veces. Las razas holando-argentina y la shorthorn han alcanzado amplia difusión en el conjunto de los departamentos de la cuenca. El índice de refinamiento lechero ha trepado de 0.45 a $72.5 \%$ durante 1937-1960 (cuadro 2 ). Este índice está mostrando que ya no conviene más tener un rodeo criollo y que, probablemente, otro conjunto de indicadores de productividad se hayan elevado en los tambos. Si se compara la proporción de ganado refinado total con la de ganado específicamente lechero, se puede apreciar que si bien la presencia de las razas hereford y aberdeen angus se han incrementado, las razas lecheras lo han hecho en una proporción muchísimo mayor. Los guarismos sobre fuertes incrementos ganaderos y de razas lecheras durante 1937-1960 hablan de un proceso de especialización láctea en curso.

La producción del bovino holando-argentino estaba asociada a "controlar sistemáticamente la producción de las hembras en lactancia y verificar -de paso- la aptitud transmisora de los machos". ${ }^{39} \mathrm{El}$ control reproductivo se vinculaba estrechamente al productivo e implicaba que el tambo contara con ciertas inversiones básicas: una balanza, un butirómetro para determinar el índice butirométrico de la leche y reactivos. El tambero debía pesar periódicamente la leche que cada animal producía durante la lactancia, identificar sus animales con, por ejemplo, números correlativos y se aconsejaba llevar planillas sobre diferentes aspectos de la producción. También, para incrementar la capacidad de producción lechera del rodeo, se debía eliminar paulatinamente a los animales de producción mediocre o escasa. ${ }^{40}$

El ganado debía estar en buen estado de nutrición, sobre todo durante el invierno, cuando no abundaban los pastos naturales, y para esto se

\footnotetext{
${ }^{38}$ No se ha podido trabajar con el Censo Nacional Agropecuario de 1969 -más próximo temporalmente al listado de cooperativas adheridas a Sancor de 1970- porque este sólo contiene datos provinciales. La metodología consistió en delimitar territorialmente la cuenca lechera con base en agregar los departamentos con orientación a la producción, comercialización y agroindustrialización láctea en cada provincia (véanse mapas 2 y 3).

39 "Ventajas", 1946, p. 331.

${ }^{40}$ García, "Porvenir", 1946, pp. 331-335.
} 


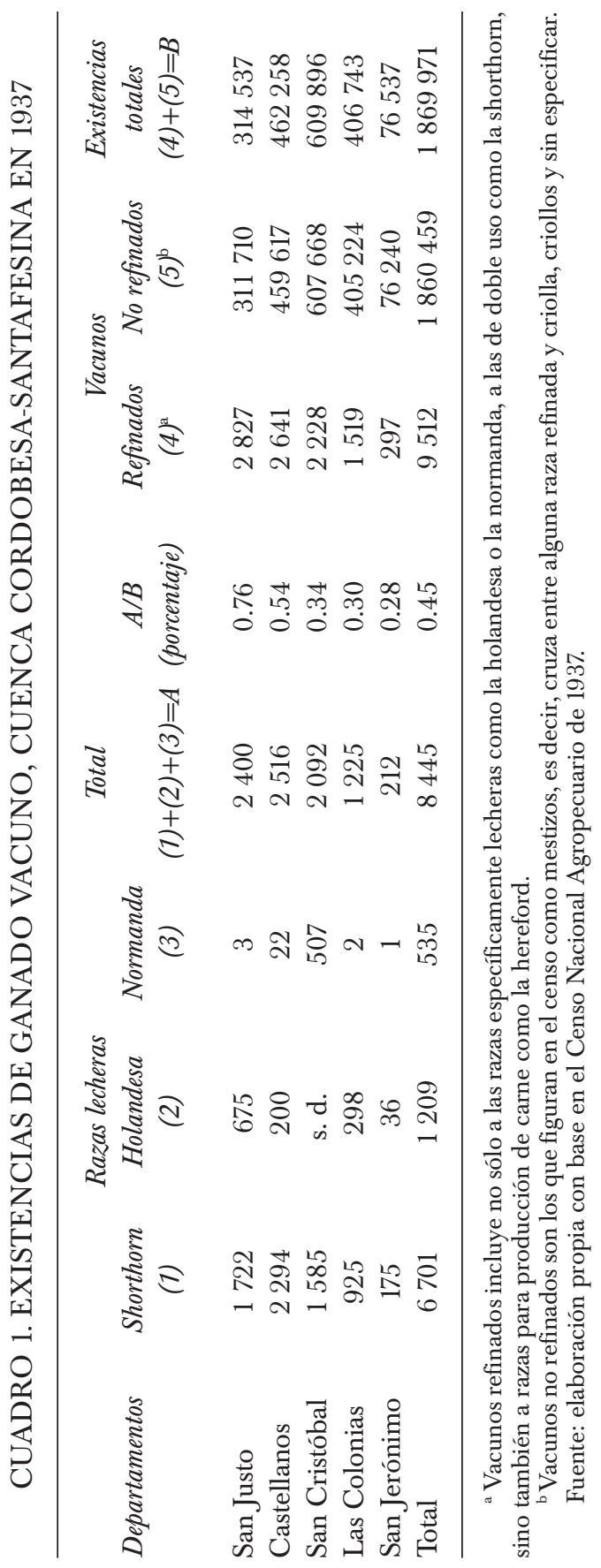




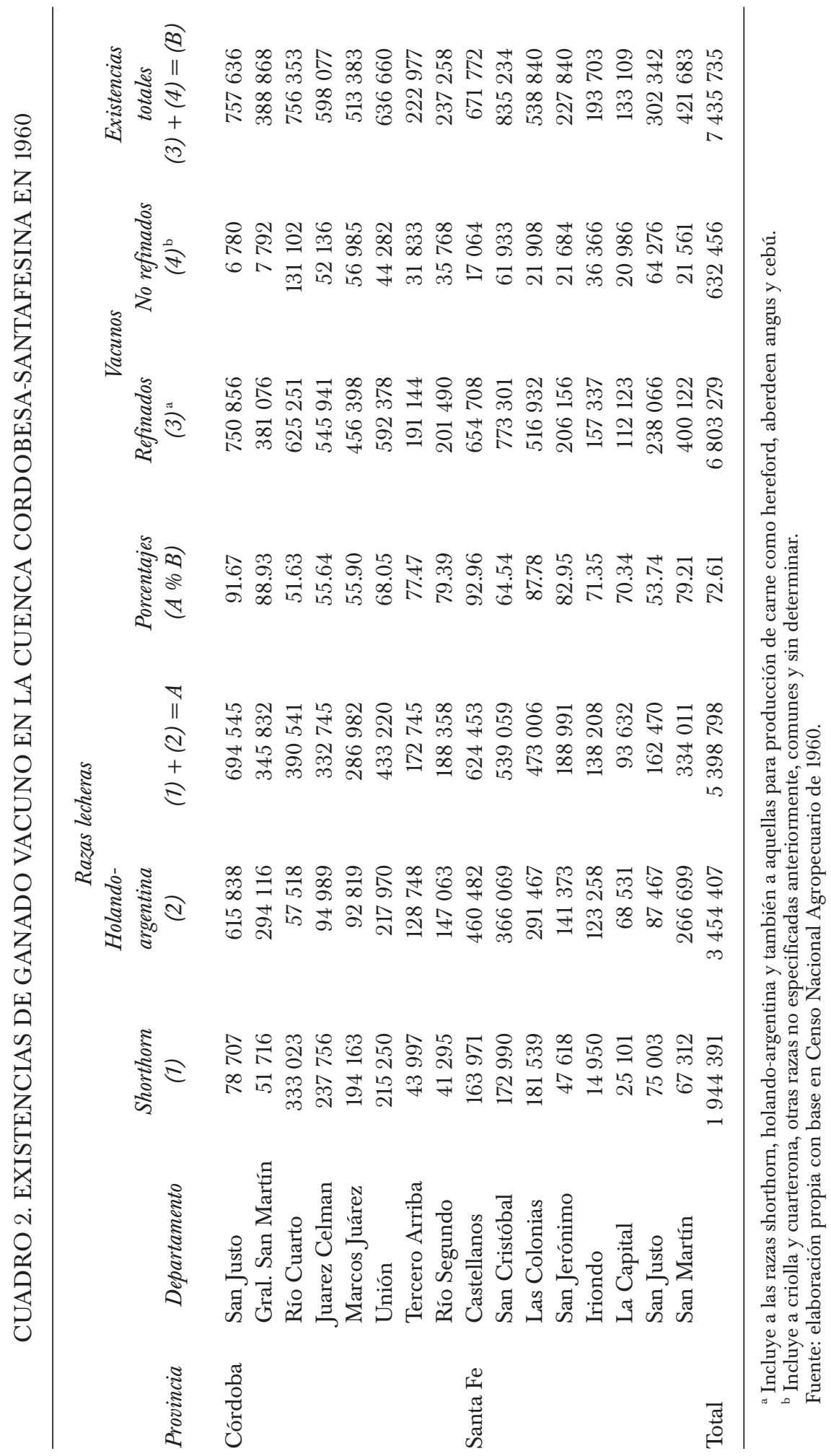




\section{GRÁFICA 1. GANADO DE RAZAS LECHERAS Y DE USO CÁRNICO EN LA CUENCA CORDOBESA-SANTAFESINA EN 1937}

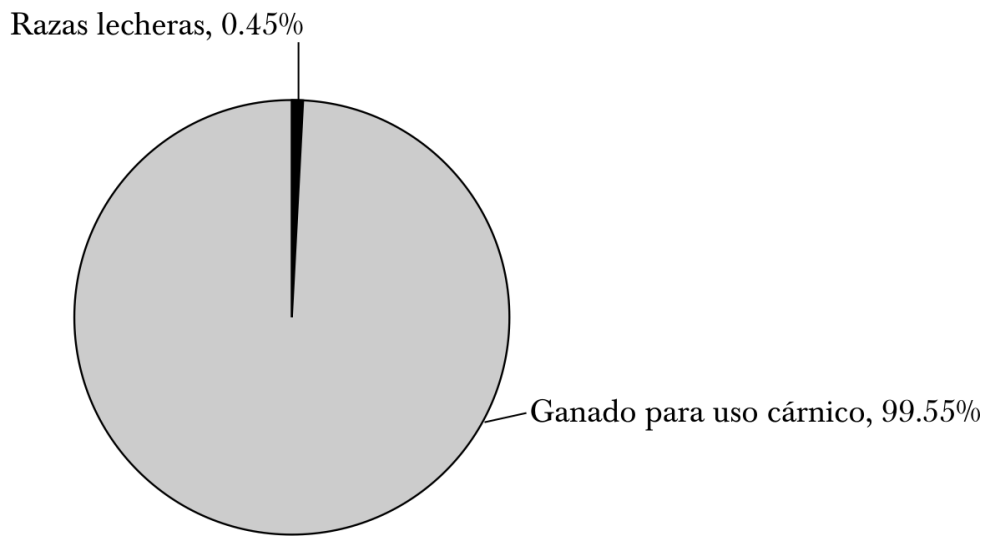

Fuente: elaboración propia con base en Censo Nacional Agropecuario de 1937.

\section{GRÁFICA 2. GANADO DE RAZAS LECHERAS Y DE USO CÁRNICO EN LA CUENCA CORDOBESA-SANTAFESINA EN 1960}

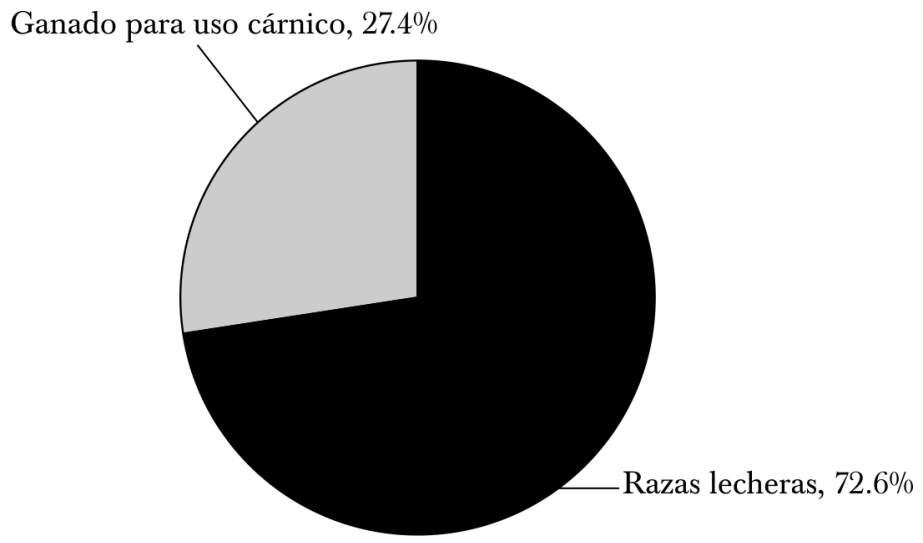

Fuente: elaboración propia con base en el Censo Nacional Agropecuario de 1960. 
aconsejaba la suplementación de la alimentación con alfalfa. Se afirmaba que por lo menos $60 \%$ de la superficie destinada al tambo debería estar cultivada con alfalfa. Se recomendaba el pastoreo rotativo, que implicaba que el productor invirtiera en potreros internos, frente al continuo, realizado sobre la superficie total del campo. ${ }^{41}$

La sanidad animal y la pasteurización ${ }^{42}$ de la leche fueron los pilares básicos para alcanzar el objetivo de una "producción sana y abundante". En la pasteurización el objetivo primordial no es la eliminación completa de los agentes patógenos, sino la disminución sensible de sus poblaciones, alcanzando niveles que no causen intoxicaciones alimentarias a los humanos. La sanidad del rebaño lechero se vinculaba al uso de ciertas instalaciones, utensilios y manejo del tambo. Para mejorar la calidad de la leche se necesitaba realizar el control periódico de la brucelosis, la mastitis y la tuberculosis. Se recomendaba que el ordeño se realizara bajo el tinglado, ya que de esta manera sería más higiénico. El tambo debería disponer, además, de equipos e instalaciones que permitieran la limpieza del tinglado y utensilios que proveyeran de suficiente agua para el ganado y facilitaran la eliminación de las aguas servidas y los residuos. ${ }^{43}$

\section{Transformaciones económicas y tecnológicas \\ en la industria y en la comercialización}

Originalmente en las cooperativas primarias se producían la crema y la caseína, y en los establecimientos fabriles la manteca. Cada cooperativa instalaba una sola cremería, aunque unas pocas tuvieron dos o tres. En las cremerías se efectuaba el descremado de la leche, primeramente con métodos muy rudimentarios y posteriormente mediante desnatadoras centrífugas. La crema obtenida de esta manera se entregaba a la fábrica de manteca y con la leche descremada, llamada suero blanco, se elaboraba la caseína. El número de socios debía ser reducido pues los productores debían tener su explotación a moderada distancia de la cremería, e incluso de la fábrica de manteca, ya que el transporte diario de la leche y la crema se hacía en carros tirados por caballos.

${ }^{41}$ Raggi, "Instalación”, 1951, pp. 161-164.

${ }^{42}$ La pasteurización es el proceso térmico realizado a líquidos (generalmente alimentos) con el objeto de reducir los agentes patógenos que puedan contener bacterias, protozoos, mohos y levaduras, etc. El proceso de calentamiento recibe el nombre de su descubridor, el químico francés Louis Pasteur (1822-1895), pionero de la microbiología moderna, en Gran, Diccionario, 1997, p. 1058.

${ }^{43}$ Raggi, "Instalación”, 1951, pp. 161-164. 
Una de las primeras cuestiones que Sancor encaró fue justamente la adquisición de una flota propia de camiones -que inicialmente fue escasa, pero cuyo tamaño fue creciendo durante la década de 1950-, e incluso la empresa abordó directamente el problema de la mejora de los caminos a través de la adquisición de máquinas motoniveladoras en la década de 1960. Otra cuestión que también fue prioritaria para la organización de segundo grado fue el otorgamiento de créditos para la compra de las desnatadoras a las cooperativas primarias. ${ }^{44}$

Desde la década de 1950 y bajo el liderazgo de Sancor la fabricación de la crema dejaba de realizarse en la cooperativa primaria. El antiguo proceso de desnate de la leche se renovaba. Se difundía la compra del equipo para el desnate de la leche que se hacía conjuntamente con el batido de la manteca y que permitía desgrasar mejor el suero y obtener así un rendimiento mayor. Una vez que se desnataba la leche, se transfería a una centrífuga, en la que se concentraba la crema hasta adquirir el contenido de la grasa de la manteca. Esto se hacía en un transmutador, el que transformaba la manteca de manera continua. Desde 1946 se decidió el procesamiento de la totalidad de la caseína producida por las cooperativas en el molino ubicado en la planta fabril de Sunchales. Este cambio se acompañó con la comercialización colectiva y directa de este producto a cargo de la empresa. ${ }^{45}$

La producción de manteca y caseína creció de manera relevante durante el periodo considerado. Se colocaban en el mercado interno y externo. No obstante, en el caso de la caseína la importancia relativa del mercado externo fue siempre mayor. La venta de manteca se incrementó de $1016651 \mathrm{~kg}$ en el balance 1940-1941 a $17050985 \mathrm{~kg}$ en el balance 19701971; en la segunda mitad de la década de 1950 y en el primer quinquenio de la década de 1960 las ventas oscilaban entre 30000000 y 23000000 de kilogramos anuales. A mediados de la década de 1960 la producción de manteca alcanzó un techo y luego comenzó a disminuir.

La manteca se exportaba y se colocaba en el mercado interno. La proporción relativa de cada mercado oscilaba anualmente. El mercado tradicional y más importante en la colocación de la manteca era Inglaterra, pero también existían otros como Paraguay, Bolivia, Chile y Alemania. Las principales casas de colocación fueron las firmas Slowson, Wester Ltd. y Boruck Ludner, según las memorias de Sancor de 1958.

El progresivo vuelco de la producción mantequera al mercado interno se asociaba a la expansión en la demanda nacional de lácteos y a la incorpora-

\footnotetext{
${ }^{44}$ Revista Sancor, núm. 176, septiembre-octubre de 1958, p. 4; núm. 183, abril-mayo de 1959, p. 25; núm. 208, abril-mayo de 1961, p. 5, y núm. 209, junio-julio de 1961, p. 9.

${ }^{45}$ Bizzozero, "Problema", 1957, p. 315.
} 

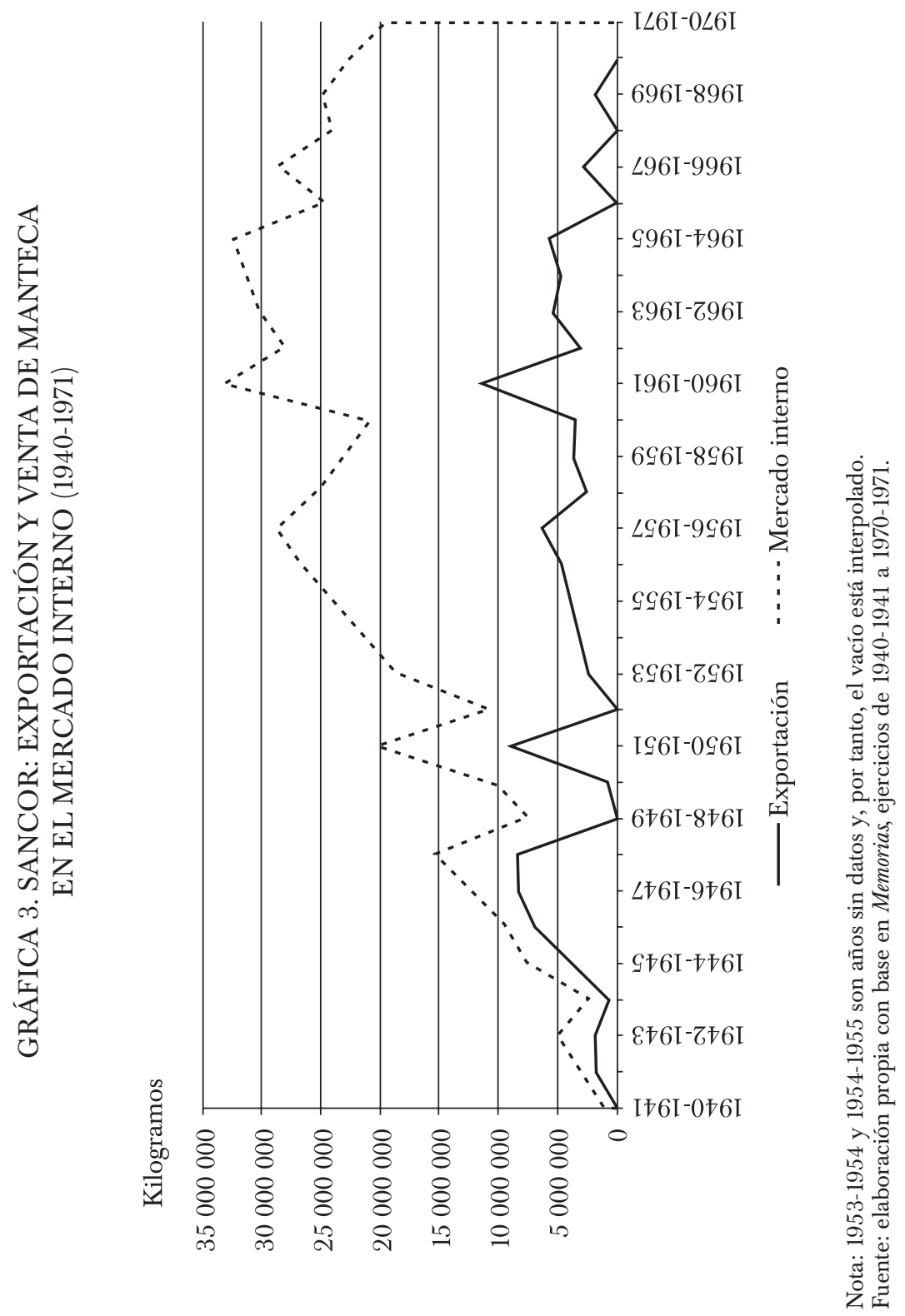


\section{GRÁFICA 4. SANCOR: MERCADOS EXTERNOS DE COLOCACIÓN DE LA MANTECA EN 1963}

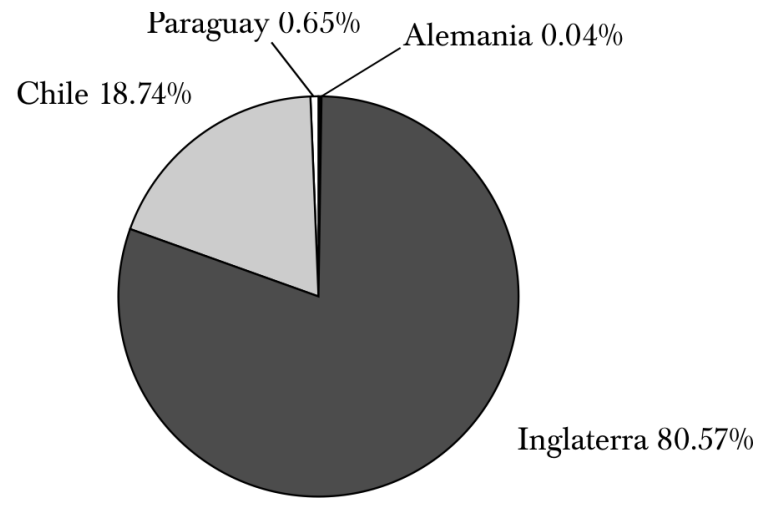

Fuente: elaboración propia con base en Memorias, ejercicio 1963-1964.

ción de la tecnología que permitía la comercialización de la manteca fraccionada en vez de blocks. La inversión en máquinas fraccionadoras tenía por objetivo acceder al comercio mayorista con marca de identificación propia, lo que debió tener una importancia crucial para poder posicionarse en el mercado local frente a otras empresas competidoras.

Para la comercialización de la manteca fraccionada se habilitaban sucursales de venta propias a partir de repartidores dueños de su propio transporte (furgones), que trabajaban por su cuenta. De esta manera se lograba abastecer al mercado capitalino de Buenos Aires, que era el que absorbía la mayor parte de la manteca, que representaba $75 \%$ del total en 1953. Se abastecía también a centros urbanos de importancia como Rosario, Córdoba o Mar del Plata a través de sucursales propias de venta. No obstante, la cadena de distribución comprendía además comercios revendedores en el centro y el noroeste del país. ${ }^{46}$

En 1963 Sancor exportaba $19615211 \mathrm{~kg}$ de láctica molida y colocaba en el mercado interno sólo $847207 \mathrm{~kg}$ de la caseína. El principal mercado de colocación era Estados Unidos de Norteamérica que absorbía 62\% de su producción. Dada la relevancia de este mercado se había instalado una oficina de negocios propia en Nueva York. No obstante, la colocación europea era significativa en su conjunto, aunque estaba distribuida en Inglaterra, Alemania, Francia, Holanda, Bélgica, Italia, Suecia y Finlandia.

${ }^{46}$ Memorias, ejercicio 1953-1954. 


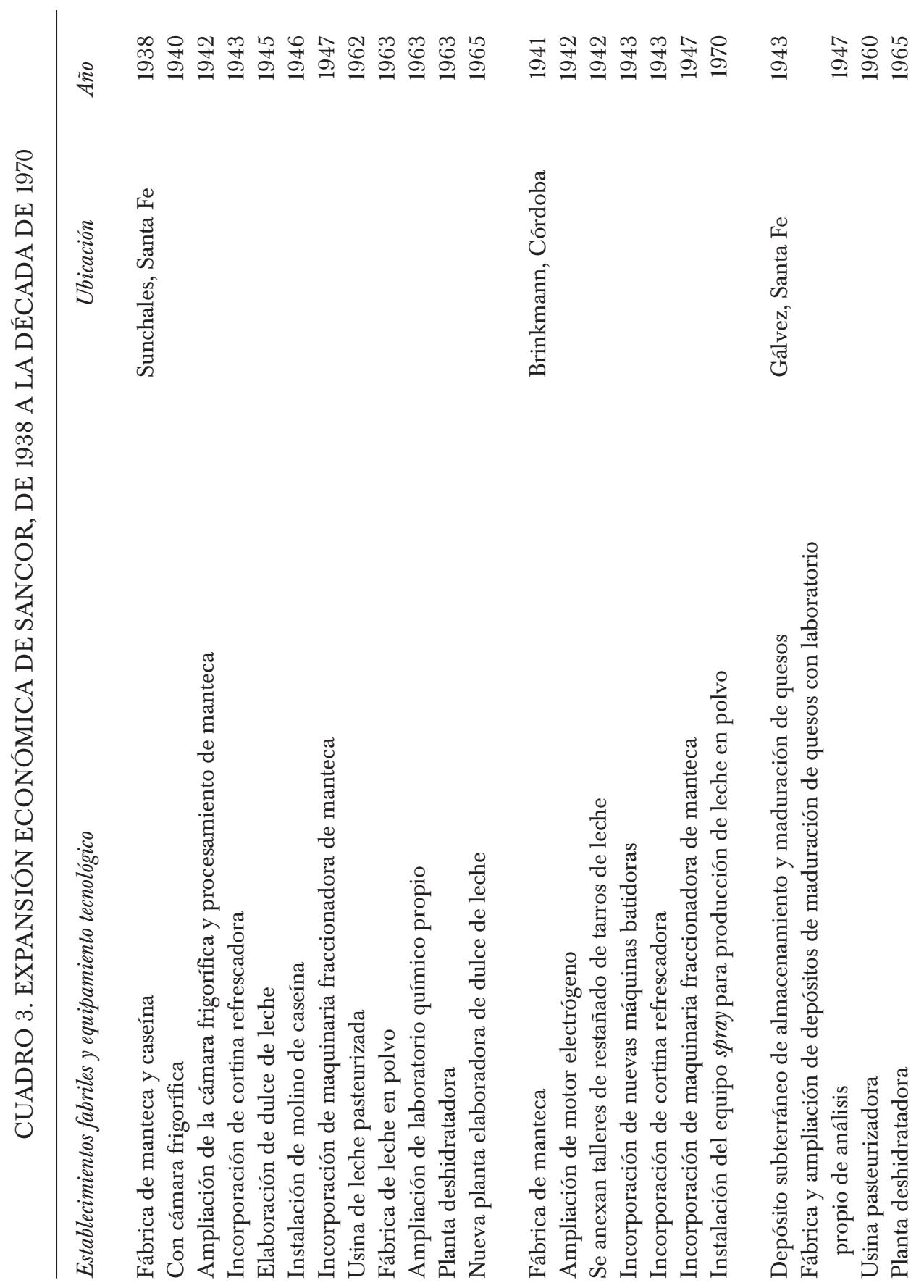




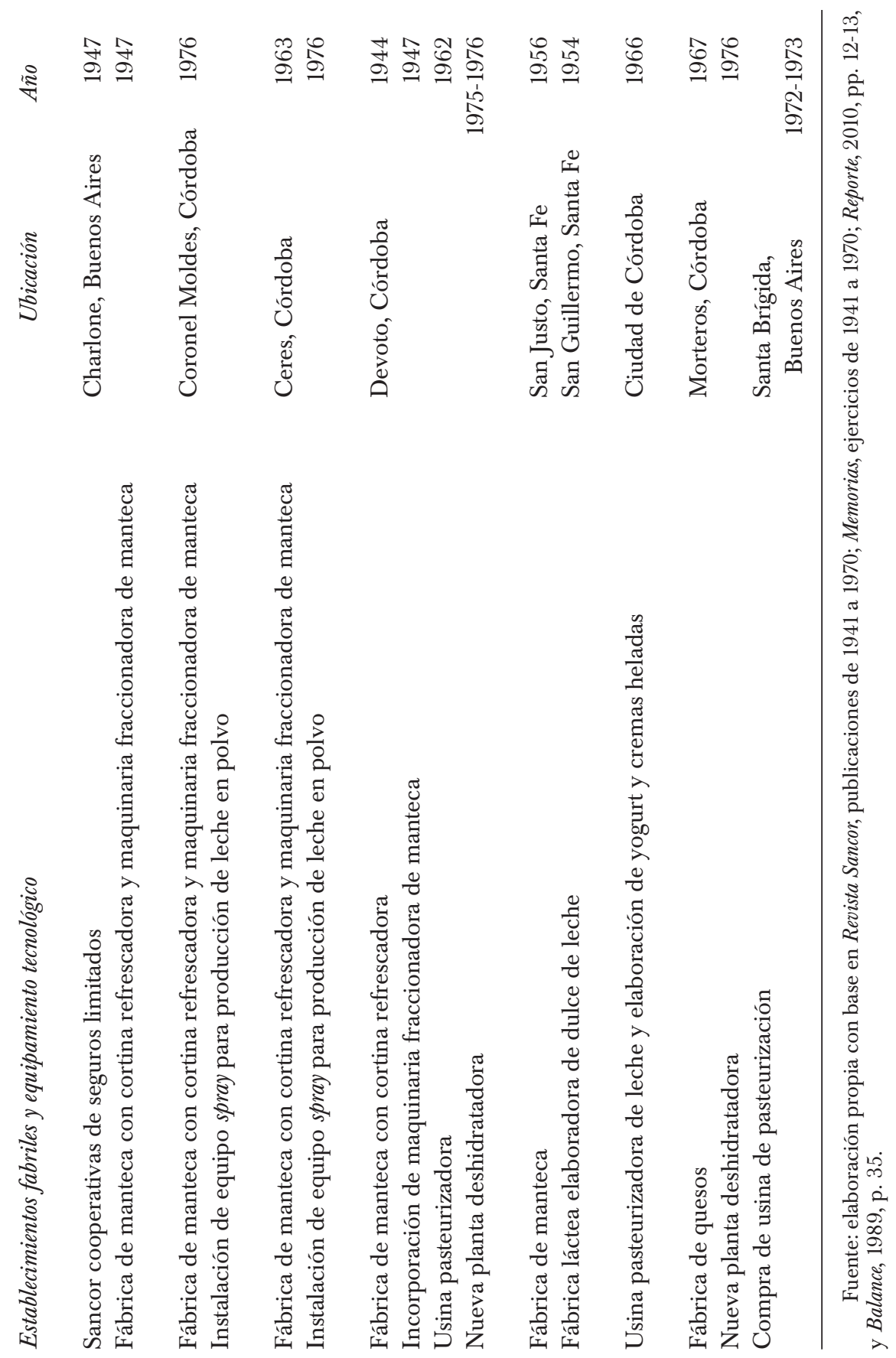




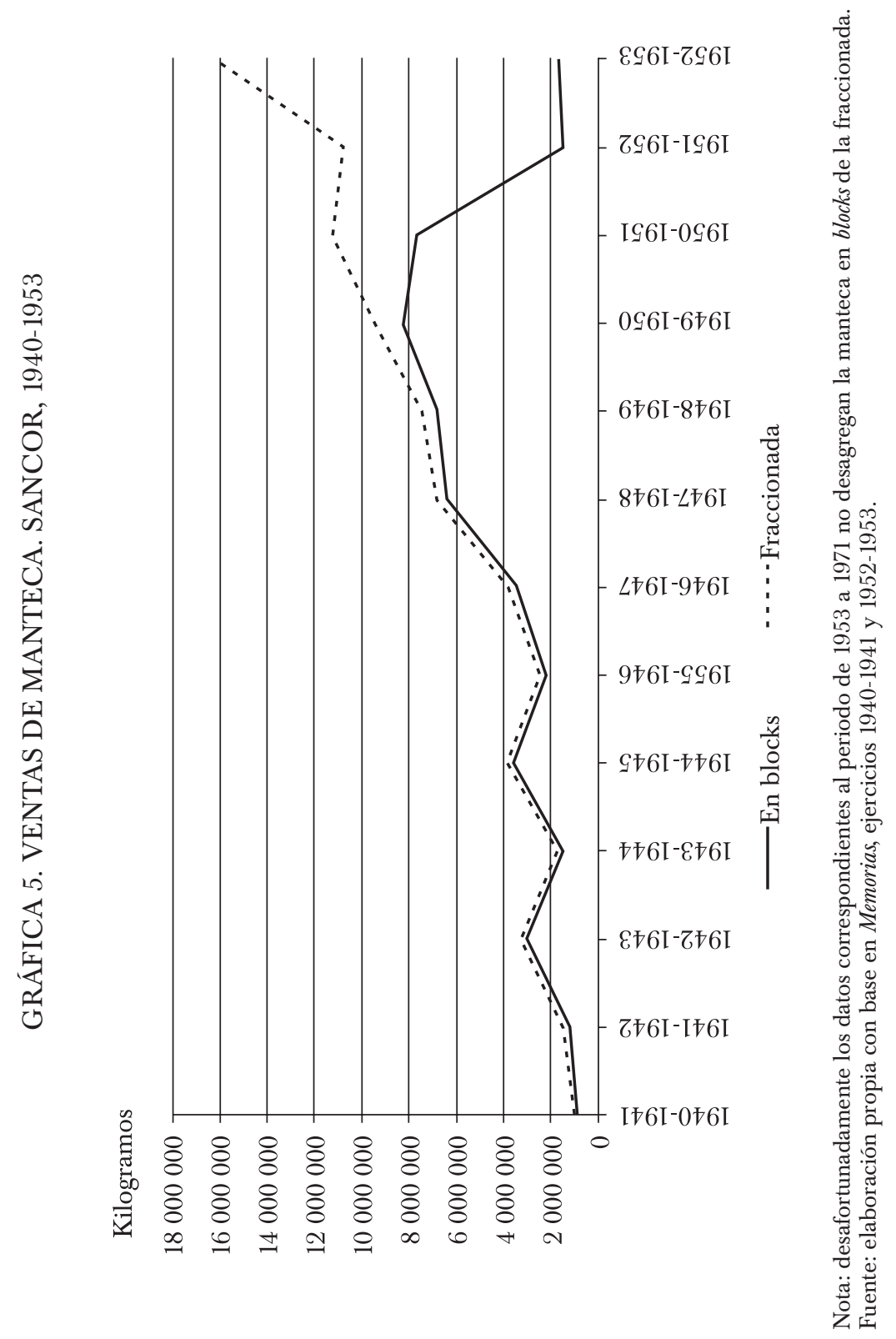




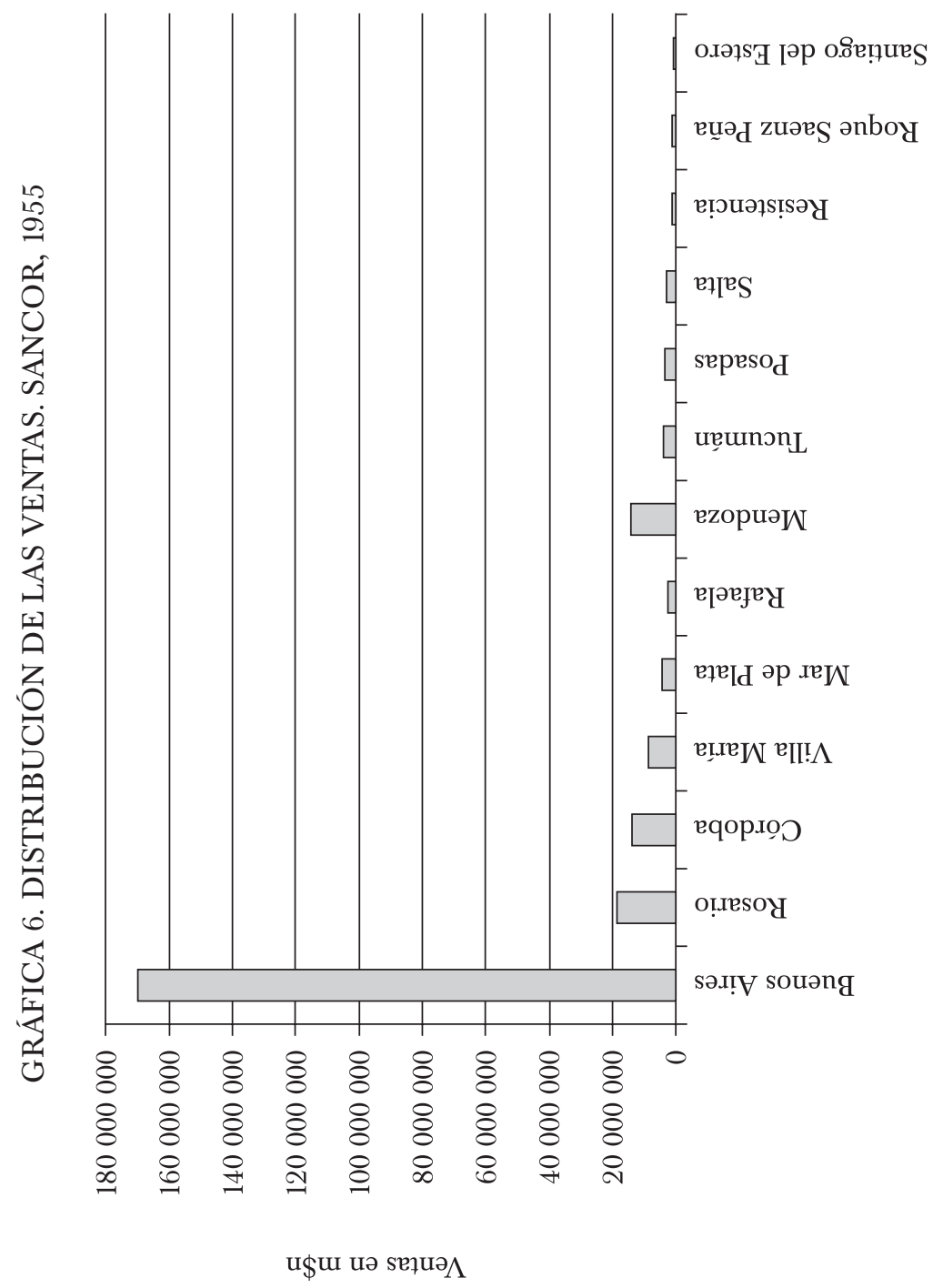

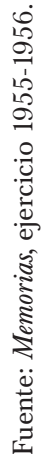




\section{GRÁFICA 7. EXPORTACIÓN DE CASEÍNA. SANCOR, 1963}

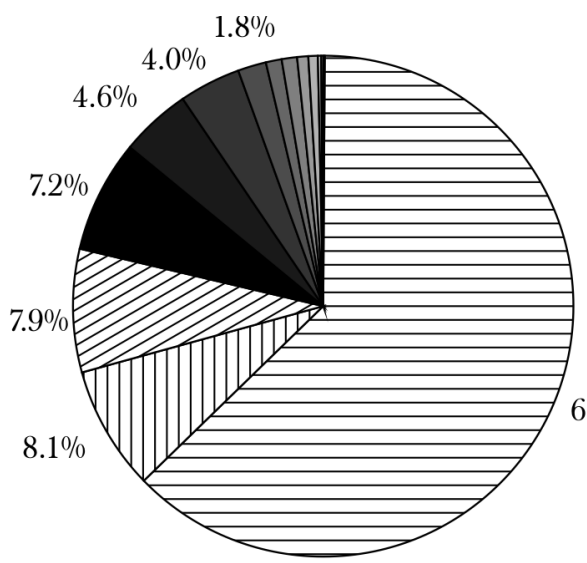

$\begin{array}{ll}\square & \text { Estados Unidos } \\ \square & \text { Inglaterra } \\ \text { Alemania } \\ \text { Japón } \\ \text { Francia } \\ \square \text { Holanda } \\ \square \text { Bélgica } \\ \square \text { México } \\ \square \text { España } \\ \square \text { Italia } \\ \square \text { Suecia } \\ \square \text { Venezuela } \\ \square \text { Finlandia } \\ \square \text { Chile }\end{array}$

Fuente: Memorias, ejercicio 1955-1956.

Como se puede observar en el cuadro 3 , la instalación de las fábricas de manteca se inició durante la década de 1940, continuó en la siguiente y se extendió incluso a la de 1960. Para la planificación técnica general se instituyó desde 1944 una jefatura general de elaboración de manteca. Con la instalación de cada fábrica de manteca se iba incrementando la capacidad productiva y se incorporaban nuevas maquinarias como batidoras, fraccionadoras, refrescadoras, etc. Por ejemplo, la fábrica de Brinkmann, comprada a Spirandelli Cía. en 1941, tenía una capacidad de producción de $3500 \mathrm{~kg}$ de manteca diarios y pasó a $10000 \mathrm{~kg}$ en sólo dos años debido a la ampliación en la disponibilidad de energía. La fábrica de Devoto fue creada para abastecer el crecimiento de Sancor hacia el sudoeste de la cuenca. Los quesos eran elaborados en las cooperativas de la Tordilla, Villa Vaudagna, Campo Mendoza, Zona de Gálvez, El Fortín y Morteros y almacenados en un depósito subterráneo construido por Sancor. Desde 1947 la empresa erigía una fábrica de quesos con laboratorio propio de análisis. En la segunda mitad de la década de 1940 la jefatura general incorporó las máquinas fraccionadoras de manteca y las cortinas refrescadoras al conjunto de las fábricas.

El estancamiento y la disminución de la producción mantequera de Sancor desde mediados de la década de 1960 tuvo como correlato la diversificación de la producción láctea por el incremento en la demanda de leches pasteurizadas, descremadas, en polvo, cremas, quesos, dulce de leche, etc., 
lo que expresaba a su vez cambios en los hábitos de consumo de la población. Sancor pudo hacer frente a los incrementos y cambios en la composición de la demanda láctea en el mercado interno a través de un conjunto de procesos de incorporación tecnológica, así como a la superación de los problemas de transporte, planteados en los orígenes de la organización.

La pasteurización de la leche y otros productos derivados tuvo una injerencia decisiva en este proceso al permitir que ciertos productos alimenticios básicos, como la leche, se pudieran transportar largas distancias sin que la descomposición los afectara y evitar de este modo la contaminación de los consumidores. Las usinas pasteurizadoras se incorporaron a los establecimientos fabriles ya existentes a principios de la década de 1960; en 1966 se creó una usina pasteurizadora para el abastecimiento de la ciudad de Córdoba y a principios de la década de 1970 otra en Santa Brígida, provincia de Buenos Aires (véase cuadro 3).

En la diversificación productiva emprendida durante la década de 1960 fue central el papel de las máquinas deshidratadoras, colectoras y enfriadoras de leche. La primera máquina deshidratadora se incorporó a la fábrica de Sunchales en 1963; durante la primera mitad de la década de 1970 se adquirieron nuevas maquinarias con capacidad de 300000 litros diarios o más para disecar leche entera o descremada. A principios de la década de 1970, Brinkmann al igual que Ceres y Moldes se convertían en centros fabriles con flexibilidad para elaborar indistintamente leche en polvo entera y descremada, crema, etcétera. ${ }^{47}$

En 1963, con el montaje de la planta deshidratadora de Sunchales, se instaló una caldera de vapor y un equipo turbogenerador que operó para el abastecimiento de las necesidades de energía del conjunto industrial de Sunchales. Se multiplicaron las plantas colectoras y enfriadoras de leche; ahí se recibía y clasificaba la leche para su posterior pago por calidad. ${ }^{48}$

\section{Los aspectos institucionales y culturales del nuevo modelo lácteo}

Si bien no se abandonó la forma legal cooperativa, el gerenciamiento experimentó transformaciones relevantes, que tomaban en referencia, de manera creciente, criterios de gestión técnica. Prevaleció una racionalidad pragmática, de tipo instrumental, que procuraba incorporar tecnologías de avanzada no sólo en la elaboración agroindustrial, sino incluso en las pautas productivas que se seguían en las explotaciones de los productores

\footnotetext{
${ }^{47}$ Balance, 1989 , p. 34.

${ }^{48}$ Ibid., y Memorias, ejercicio 1963-1964.
} 
asociados a las cooperativas para poder competir, afianzarse y crecer en los mercados.

El énfasis puesto en la observancia de criterios de gestión técnica por sobre prácticas derivadas de la doctrina cooperativa tales como la participación activa de los asociados en la toma de decisiones se pone en evidencia en la modificación de sus estatutos sociales -tan tempranamente como en 1942- y en los cambios en la estructura de gerenciamiento, en coherencia con las modificaciones jurídicas. ${ }^{49}$ La forma originaria de gestión agroindustrial implicaba la representación directa de los consejos directivos de cada una de las cooperativas primarias asociadas en el directorio, espacio crucial en la toma de decisiones. Pronto se transitó hacia formas de representación más delegadas. Simultáneamente, la gerencia tenía una creciente injerencia en el directorio. Además, los cargos técnico-gerenciales crecían en número y relevancia al interior de la institución.

A principios de la década de 1940, cuando aumentaba vertiginosamente el número de cooperativas adheridas, las reuniones de los directores de las cooperativas dejaban de ser adecuadas a los procesos de toma de decisiones. Las reuniones del directorio se convertían en "verdaderas asambleas", debido al alto número de participantes. Para solucionar este problema, en 1941 se estableció una mesa ejecutiva del directorio -integrada por un presidente, un vicepresidente, un secretario, un tesorero, un prosecretario y un protesorero- que se reunía semanalmente, mientras que el directorio en pleno se comenzaría a reunir sólo una vez por mes. Desde la asamblea ordinaria de 1943 se iniciaba la aplicación de la reforma estatutaria de 1942, por la cual el directorio dejaba de responder de manera directa a los directores de las cooperativas primarias. Se afirmaba que este nuevo sistema permitiría "encarar la venta en gran escala, pero para ello es menester dar amplia libertad al directorio porque, de otro modo, poniéndose trabas mediante consultas previas con los interesados se pierde un tiempo precioso y se malogran oportunidades favorables para el negocio". ${ }^{50}$

Se observa que este modelo generaba ciertas tensiones entre los valores cooperativos y el desempeño organizacional. Se proponía que el aporte de producción de las cooperativas primarias guardara proporción con su injerencia en la toma de decisiones, cuando el cooperativismo establece que es suficiente poseer una sola acción para participar igualitariamente en las decisiones de la organización. Otro ejemplo ilustrativo es que cuando la capacidad de industrializar la producción láctea y la demanda del mercado interno crecieron a un ritmo más acelerado que la capacidad de

${ }^{49}$ Orígenes, 1988, pp. 123-130, y Los primeros, s. a., pp. 235-238.

${ }^{50}$ Los primeros, s. a., p. 130. 
abastecimiento proveniente del número creciente de cooperativas adheridas, se comenzó a comprar leche para pasteurizar a tambos no asociados a cooperativas - por fuera de esta cuenca-, como fue el caso de las compras a productores que trabajaban con La Vascongada, S. A., o a Estancias San Miguel S. A. Con estas prácticas se estaba transgrediendo el principio cooperativo que dicta que sólo es posible abastecerse con la producción cooperativa. ${ }^{51}$

Ya a principios de la década de 1960 el directorio respondía básicamente a una gerencia general y no a la asamblea originaria de representantes cooperativos. Esta gerencia general estaba, a su vez, sustentada en un conjunto de departamentos y subdepartamentos gerenciales, tales como los departamentos de industria, administrativo, relaciones y producción primaria, comercio interior, comercio exterior; subgerenciales, tales como el de compras y almacenes, transportes y construcciones. Estos departamentos estaban asesorados por diferentes comisiones técnicas, entre estas, asuntos industriales, administrativos, comerciales y producción primaria.

La generación y el desarrollo de estos órganos de gestión gerencial cooperativa implicaban el despliegue de un conjunto de capacidades organizacionales. La entidad de segundo grado gestionaba y otorgaba avales crediticios a las cooperativas para la adquisición de maquinaria a través de la banca estatal, principalmente el Banco de la Nación Argentina y el Banco de Crédito Industrial Argentino. ${ }^{52}$ Otras cuestiones que ejemplifican esta cuestión son el acceso directo a los mercados externos y a la instalación de talleres mecánicos. Para evitar que los productores tuvieran que comprar los animales refinados a las cabañas, directivos de Sancor organizaban viajes a Holanda con el fin principal de seleccionar reproductores bovinos holando para distribuir entre socios de la organización. Sancor organizaba, además, viajes a Estados Unidos de Norteamérica para estudiar el mercado y vender de manera ventajosa la caseína de las cooperativas primarias. ${ }^{53}$ Sancor instaló además, talleres mecánicos, verdaderos nervios motores de la empresa, especializados en la reparación tanto de los automotores como de las descremadoras centrífugas y las balanzas, carpintería, ajuste de motores y montaje de fábricas, electricidad, pintura, reparación y restañado de tarros, fabricación y arreglo de equipos y construcciones.

La cultura cooperativa que impregnaba a los órganos de gestión profesional y técnica propiciaba una estrecha vinculación económica entre la entidad de segundo grado y las cooperativas primarias asociadas e integra-

${ }^{51}$ Revista Sancor, núm. 41, noviembre-diciembre de 1945, pp. 15-16; núm. 83, septiembreoctubre de 1949, pp. 8-9; núm. 93, junio-julio de 1950, p. 31; núm. 176, septiembre-octubre de 1958, p. 14, y núm. 294, febrero-marzo de 1969, p. 7.

${ }_{52}$ Olivera, "Agroindustria", 2011.

${ }^{53}$ Memorias, ejercicios 1955-1956 y 1969-1970. 
DIAGRAMA 1. GERENCIA DE SANCOR EN 1962

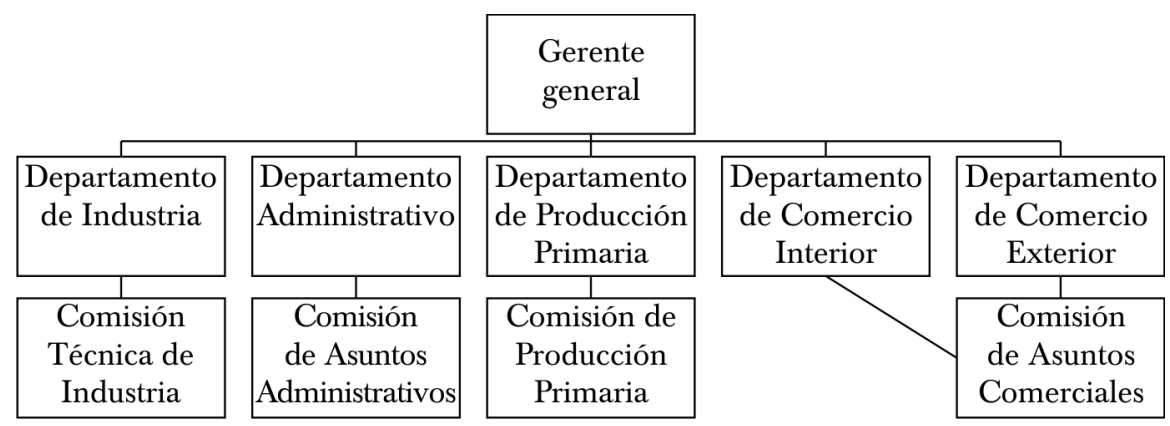

Fuente: elaboración propia con base en Memorias, ejercicio 1962-1963.

ción social entre directivos, técnicos, productores y trabajadores. Desde sus orígenes existían encargados cremeros y otros contables de Sancor en cada cooperativa primaria. Los primeros recibían la producción del tambo y promovían el mejoramiento de los índices de grasa butirométrica en la leche. Operaban como enlace entre la entidad de segundo grado y la cooperativa primaria en la transmisión de un conjunto de innovaciones en el tambo. Los encargados contables eran "consejeros obligados de la organización de primer grado”.

La actitud innovadora en materia de tecnología se erigió como un valor cultural al que aspiraba la comunidad local. La difusión de escuelas de capacitación en cremerías y de asesorías en servicios de sanidad animal, control veterinario, higiene de tambos y producción lechera constituyen expresiones de esta cuestión. El pago a los productores según la calidad de la leche, pauta incorporada en 1965, denominada tipificación de la leche fluida, operaba como incentivo a la innovación tecnológica en los tambos. El sustrato cultural de esta pauta remitía a la internalización del nuevo modelo lácteo en las prácticas de los actores.

\section{REFLEXIONES FINALES}

La trama productiva y social inicial de la cuenca cordobesa-santafesina hasta la década de 1930 estaba caracterizada por el desarrollo de la actividad láctea en el contexto de una economía agraria diversificada en la cual existía la chacra mixta, diversas empresas y asociaciones. Diferentes proyectos cooperativos eran sustentados por colonos inmigrantes que bus- 
caban a través de estas experiencias replicar experiencias colectivas de sus países de origen.

Esta trama va a experimentar relevantes transformaciones bajo el liderazgo de la gran empresa cooperativa Sancor, la cual va a recorrer el camino hacia la especialización láctea, se va a expandir sobre antiguas cuencas lecheras y áreas de vocación agrícola, y va a incorporar tecnologías de avanzada en el tambo y la industria.

Un factor clave que explica el conjunto de las transformaciones sobre las que se ha querido dar cuenta sucintamente en este texto es la cultura cooperativa de tipo empresarial que impregna el accionar de los actores y el despliegue de las capacidades organizacionales. Este cooperativismo difundía valores culturales que propiciaban condiciones para competir en los mercados lácteos, la gestación y el desarrollo de un nuevo modelo lácteo empresarial. La cultura cooperativa que impregnaba a los órganos de gestión profesional y técnica propiciaba, entre otras cuestiones, una estrecha vinculación económica entre la entidad de segundo grado y las cooperativas primarias, y la integración social entre directivos, técnicos, productores y trabajadores.

\section{FUENTES CONSULTADAS}

Archivos

AS Archivo de Sancor, Santa Fe, Argentina.

AINTA Archivo del Instituto Nacional de Tecnología Agropecuaria, Manfredi Córdoba, Argentina.

BCEUNC Biblioteca de Ciencias Económicas de la Universidad Nacional de Córdoba.

\section{Bibliografía}

V Censo General de la Nación, Buenos Aires, Dirección General de Estadísticas, 1947, t. II.

Balance 1838-1988, Santa Fe, Producciones Gráficas, septiembre de 1989.

Barsky, Osvaldo y Jorge Gelman, Historia del agro argentino. Desde la conquista hasta fines del siglo XX, Buenos Aires, Grijalbo, 2001.

Bizzozero, Fernando, "El problema de las vacas lecheras. Contribución al mejoramiento de la producción láctea” en Dirección DE InformaCiOnes, Almanaque del Ministerio de Agricultura de la Nación, Buenos Aires, Dirección de Informaciones, 1947, pp. 339-341. 
"El problema de las vacas lecheras. Contribución al mejoramiento de la producción láctea" en Dirección DE Informaciones, Almanaque del Ministerio de Agricultura de la Nación, Buenos Aires, Dirección de Informaciones, 1957, p. 315.

Censo Nacional Agropecuario de 1960, Buenos Aires, Dirección Nacional de Estadísticas, 1964 , tt. II y III.

Censo Nacional Agropecuario. Tomo Ganadero. Industrias derivadas, Buenos Aires, Ministerio de Agricultura, 1937.

Dorfman, Adolfo, Historia de la industria argentina, Buenos Aires, Editorial SolarHachette, 1970.

Ferrari, Horacio, La industria lechera en la economía agraria argentina, Buenos Aires, El Ateneo, 1978.

Ferrero, Roberto y Fermín Cravero, Origen y desarrollo de la industria lechera argentina. II parte (1880-1940), Córdoba, edición de los autores, 1988.

GARCÍA, DANIEL, "El porvenir de la raza holando-argentina en el país" en DireCCión DE Informaciones, Almanaque del Ministerio de Agricultura de la Nación, Buenos Aires, Dirección de Informaciones, 1946, pp. 331-335.

GeLler, LUCIO, "El crecimiento industrial argentino hasta 1914 y la teoría del bien primario exportable" en JimÉnEZ ZAPIOLA (comp.), El régimen oligárquico. Material para el estudio de la realidad argentina (hasta 1930), Buenos Aires, Amorrurtu, 1975.

Gerchunoff, Pablo y Lucas Llach, El ciclo de la ilusión y el desencanto. Un siglo de políticas económicas argentinas, Buenos Aires, Ariel Sociedad Económica, 2000.

Gran Espasa Ilustrado, Diccionario enciclopédico, Madrid, Espasa Calpe, 1997.

LATTUADA, MARIO y JUAN MAURICIO RENOLD, El cooperativismo agrario ante la globalización, Buenos Aires, Siglo Veintiuno/Argentina, 2004.

Lipartito, Kenneth, "Culture and the Practice of Business History", Business and Economic History, Business History Conference, vol. 24, núm. 2, 1995.

Los primeros diez años. Génesis, constitución y siete años de marcha, Sunchales, Sancor Cooperativas Unidas Limitadas, s. a.

MAUBECIN, RAMÓN, "El crédito bancario en la promoción de la producción lechera", Instituto Nacional de Tecnología Agropecuaria, Información técnica, Argentina, Manfredi, 1972, núm. 45, pp. 2-5.

Memorias y balances, Santa Fe, Sancor Cooperativas Limitadas, diversos ejercicios década de 1940 a 1972.

Molinari, Romina. "Viejos y nuevos reclamos de los productores de leche en la Argentina (1950-2007). Algunas aproximaciones sobre la cuenca de coronel Moldes y región", tesis de licenciatura, Argentina, Universidad Nacional de Río Cuarto, 2009.

Olivera, Gabriela, "Agroindustria láctea, regulación estatal y cooperativismo (19301955)", Mundo Agrario. Revista de Estudios Rurales, vol. 11, núm. 22, Universidad Nacional de la Plata, julio de 2011, <www.mundoagrario-unlp.edu.ar/numeros/no-22-/er-sem-2011/agroindustria-lactea-regulacion-estatal-y-cooperativismo-1930-1955>. [Consulta: 15 de enero de 2012]. 
"Cooperativismo agrario y gremialismo chacarero en tiempos de crisis" en Silvia LÁzZaro y Javier Balsa (coords.), Política y agro (1930-1943), Buenos Aires, Ciccus, 2012.

Orígenes y nacimiento de Sancor, Santa Fe, Sancor Cooperativas Limitadas, 1988.

Posada, Marcelo y Alfredo Pucciarelli, "La producción láctea argentina a través del CNA '88. Un estudio de la cuenca de abasto a Buenos Aires" en Osvaldo Barsky y Alfredo Pucciarelli (eds.), El agro pampeano. El fin de un periodo, Buenos Aires, Facultad Latinoamericana en Ciencias Sociales, 1977.

Raggi, Carlos Alberto, "Instalación y manejo de un tambo" en Dirección DE INformaciones, Almanaque del Ministerio de Agricultura de la Nación, Buenos Aires, Dirección de informaciones, 1951, pp. 161-164.

Reporte de sostenibilidad, 2009-2010, Santa Fe, Logro Producciones Gráficas, 2010.

Revista Sancor, Órgano bimestral de fábricas de manteca Sancor Cooperativas Unidas Ltda., año I, núm. 1, junio-julio de 1942; año III, núm. 41, noviembre-diciembre de 1945; año VIII, núm. 83, septiembre-octubre de 1949; año VIII, núm. 93, junio-julio de 1950; año XVI, núm. 167, enero-febrero de 1958; año XVI, núm. 167, enerofebrero de 1958; año XVII, núm. 176, septiembre-octubre de 1958; año XVII, núm. 183, abril-mayo de 1959; año XIX, núm. 208, abril-mayo de 1961; año XX, núm. 209, junio-julio de 1961; año XXVII, núm. 294, febrero-marzo de 1969; año XXVII, núm. 295, abril-mayo de 1969; año XxxiI, núm. 367, abril-mayo de 1976, y año XXXV, núm. 394, abril-mayo de 1979; Argentina.

Rodriguez TARDiti, José, Juan B. Justo y Nicolás Repetto en la acción cooperativa, Buenos Aires, Intercoop Editora Cooperativa Limitada, 1970.

"Ventajas del contralor de productividad de los tambos en general" en DiRECCIÓN DE Lechería, Almanaque del Ministerio de Agricultura de la Nación, Buenos Aires, Dirección de Informaciones, 1946, p. 331.

Weber, Max, Economía y sociedad, México, Fondo de Cultura Económica, 1984.

YURI IZQUIERDO, MARIO, Quince años en el cooperativismo agrario argentino (1953-1968), Buenos Aires, Intercoop Editora Cooperativa Limitada, 1972. 